(c) American Dairy Science Association, 2003.

\title{
Follicular Size and Response to Ovsynch Versus Detection of Estrus in Anovular and Ovular Lactating Dairy Cows
}

\author{
A. Gümen, J. N. Guenther, and M. C. Wiltbank \\ Department of Dairy Science, \\ University of Wisconsin-Madison, Madison, WI, 53706
}

\begin{abstract}
In a commercial dairy herd, 316 lactating Holsteins were studied to determine the percentage of anovular cows, to examine follicular sizes in anovular cows, and to compare synchronized ovulation (Ovsynch) versus detection of estrus on fertility of ovular and anovular cows. Ultrasonography examinations at 47 to $53 \mathrm{~d}$ and at 54 to $60 \mathrm{~d}$ postpartum were used to measure follicles and to classify cows as ovular or anovular. Anovular cows were identified as those with no detectable luteal tissue by ultrasonography and by low progesterone in blood samples collected weekly. Anovular cows included $28 \%$ of 122 primiparous cows and $15 \%$ of 194 multiparous cows. Of 64 anovular cows, $20 \%$ had follicles $\geq 25$ $\mathrm{mm}$ that might be considered cystic (4\% of total cows), $58 \%$ had 15 - to $24-\mathrm{mm}$ follicles, and $22 \%$ had 9- to $14-$ $\mathrm{mm}$ follicles. Cows identified as ovular and anovular were randomly assigned within cyclic status to one of two artificial insemination (AI) strategies: 1) AI after detected estrus during $21 \mathrm{~d}$, or 2) timed AI after a 10d Ovsynch protocol. Weekly ultrasonography continued for $21 \mathrm{~d}$ to detect ovulations. For the Ovsynch subgroups, $97 \%$ of ovular and $94 \%$ of anovular cows ovulated after the second GnRH injection. Within $21 \mathrm{~d}$, spontaneous ovulations for the detection of estrus subgroups were $42 \%$ of anovular cows vs. $89 \%$ of ovular cows. Conception rates were greater for ovular cows regardless of treatment, but conception rates between respective Ovsynch and estrus detection groups for ovu$\operatorname{lar}(32 \%, 35 \%)$ or anovular $(9 \%, 11 \%)$ cows were similar. Although $20 \%$ of lactating cows were not cyclic by about $60 \mathrm{~d}$ postpartum, nearly all ovulated following Ovsynch. However, anovular cows had lower conception than ovular cows whether inseminated after detected estrous or after Ovsynch.
\end{abstract}

(Key words: anovulation, conception rate, Ovsynch, estrus)

Received November 11, 2002

Accepted May 13, 2003.

Corresponding author: M. C. Wiltbank; e-mail: wiltbank@calshp. cals.wisc.edu.
Abbreviation key: $\mathbf{C L}=$ corpus luteum or corpora lutea, $\mathbf{C R}=$ conception rate, $\mathbf{P R}=$ pregnancy rate .

\section{INTRODUCTION}

In previous studies, anovular dairy cows have generally been classified as having follicular cysts or being anestrous without growth of large follicles (Beam and Butler, 1997; Garverick, 1997; Opsomer et al., 1998). Follicular cysts are usually diagnosed based on palpation per rectum and are classically defined as large (generally $>25 \mathrm{~mm}$ in diameter) anovular follicles that persist on the ovary for at least $10 \mathrm{~d}$ in the absence of a corpus luteum $(\mathbf{C L})$. Several researchers have shown that palpation per rectum is not accurate for classification of cysts (follicular or luteal cysts) with 58 to $65 \%$ accuracy reported (Nakao et al., 1983; Sprecher et al., 1988). In contrast, ultrasonography was much more accurate $(85.1 \%)$ than rectal palpation $(51.1 \%)$ for classifying ovarian cysts as follicular or luteal cysts (Farin et al., 1992). Some researchers have also reported the follicular dynamics that result in anovular dairy cows during the postpartum period; however, the incidence of this problem could not be determined due to limited numbers of cows (Staples et al., 1990; Beam and Butler, 1997). Recently, we have proposed that classification of anovular cows by maximal follicular sizes might be useful in determining the underlying physiology producing anovulation (Wiltbank et al., 2002). In the current study, that classification system was used in classifying anovular cows in a commercial dairy farm. This also allowed evaluation of any possible relationship between the maximal follicular size of cows and milk production or BCS.

Treatments with GnRH have been used in estrus synchronization protocols to improve reproductive management. Pursley et al. (1995) reported a method for timed AI using GnRH and $\mathrm{PGF}_{2 \alpha}$ in which ovulation was synchronized within an 8-h period (Ovsynch program). This precise synchrony allows for successful AI without the need to detect estrus (Pursley et al., 1995; 1997a; 1997b; Stevenson et al., 1999; Vasconcelos et al., 1999). Previous studies compared the Ovsynch program to $\mathrm{PGF}_{2 \alpha}$ injections $14 \mathrm{~d}$ apart (Tenhagen et al., 
2001), GnRH and $\mathrm{PGF}_{2 \alpha}$ injections (7 d apart) with detection of estrus (Stevenson et al., 1999; Bartolome et al., 2000), or a herd management system that relied on detection of estrus, a.m./p.m. breeding, and periodic use of $\mathrm{PGF}_{2 \alpha}$ (Pursley et al., 1997a). There have been some reports on the use of Ovsynch in anovular cows (Bartolome et al., 2000; Pursley et al., 2001; Cordoba and Fricke, 2002) with reported conception rates of 24 to $35 \%$. Those reports had classified cows as anovular based on progesterone concentrations in two blood samples taken at a 10-d interval (Pursley et al., 2001; Cordoba and Fricke, 2002) or cows with no CL and multiple follicles $(>20 \mathrm{~mm}$ in diameter) by palpation per rectum (Bartolome et al., 2000). To further this research area, there were three objectives in the current research project: 1) to determine the percentage of anovular cows in a commercial dairy herd, 2) to determine the size of follicles in anovular cows, and 3) to compare Ovsynch vs. estrus detection in ovular and anovular cows. To complete these objectives, anovular cows were identified based on progesterone concentrations and transrectal ultrasonography in a commercial dairy herd. Weekly ultrasonography and circulating progesterone were also used to determine spontaneous recovery from anovulation and response to Ovsynch.

\section{MATERIALS AND METHODS}

This experiment was conducted on one commercial dairy herd (approximately 800 lactating Holstein dairy cows) located in southeastern Wisconsin. Cows were fed twice daily with a high-energy lactating dairy cow diet fed as a TMR following NRC recommendations. All cows in the trial were kept in the fresh pen until moved into one of two early-lactation pens depending on their milk production. The cows were milked three times a day and were housed in a free-stall facility. Herd personnel were responsible for reproductive management including estrus detection and AI. Daily milk yield, reproductive, health, and management records for each cow were collected on Dairy Comp 305 (Valley Agricultural Software, Tulare, CA). Trans-rectal ultrasound evaluation to monitor ovarian structures was performed with an ultrasound scanner (Aloka 500V, Corometrics Medical Systems Inc., Wallingford, CT) equipped with a 7.5 MHz linear-array transducer. Measurements were made on a single frozen image of the apparent maximal area of each follicle, using the average diameter in two directions at right angles. The experimental protocol is summarized in Figure 1. Cows were evaluated with ultrasound two times to determine cyclicity between 47 to 53 and 54 to $60 \mathrm{~d}$ postpartum. Cows $(\mathrm{n}=316)$ were divided into two groups, ovular (presence of CL) or anovular (no CL). Anovular cows

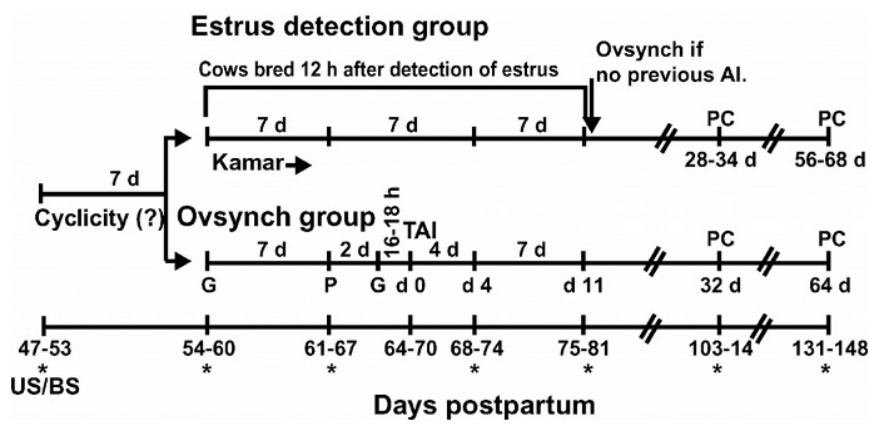

Figure 1. Experimental protocol used for detection of estrus and Ovsynch groups. The reproductive tracts of cows were evaluated by ultrasound (US) and blood samples (BS) were collected $7 \mathrm{~d}$ apart, between 47 to 53 and 54 to $60 \mathrm{~d}$ postpartum (PP) to determine cyclicity. Ultrasound evaluations and blood sampling days are shown by asterisks. Estrus detection group: A Kamar was placed on cows in estrus detection group after the second ultrasound evaluation (54 to $60 \mathrm{~d}$ ). Cows were inseminated $12 \mathrm{~h}$ after detection of estrous. Cows were evaluated by ultrasound and blood samples were collected weekly for three more weeks (21-d experimental period). At the end of the 21-d experimental period, all cows that had not been inseminated were treated with the Ovsynch program. Pregnancy check (PC) was performed by ultrasonography at 28 to $34 \mathrm{~d}$ and 56 to $68 \mathrm{~d}$ after AI. Ovsynch group: The Ovsynch program was started at 54 to $60 \mathrm{~d}$ PP (GnRH [G]-7 d-PGF $2 \alpha$ [P]-2 d-[G]-16-18 h-timed AI [TAI]). Cows were evaluated by ultrasound and blood samples were collected weekly until d 11 after AI. A pregnancy check was performed by ultrasonography at 32 and $64 \mathrm{~d}$ after AI.

were divided into three groups based on the maximal size of any follicle detected by ultrasound scanning at either of the two time points. Groups were cystic size (follicle or follicles $\geq 25 \mathrm{~mm}$ in diameter), ovular size to cystic size (15 to $24 \mathrm{~mm}$ ), or deviation from cohort follicles to ovular size (9 to $14 \mathrm{~mm}$ ). Ovular and anovular cows were randomly assigned to one of two groups: estrus detection or Ovsynch. Cows in the estrus detection group were inseminated by the a.m./p.m. rule following estrus detection by either visual detection or Kamar device activation (KAMAR, Kamar Inc., Steamboat Springs, CO) during the next $21 \mathrm{~d}$. Cows in the Ovsynch group were inseminated by appointment following the Ovsynch program. Cows had ovaries evaluated with ultrasound weekly during the 21-d period to detect ovulations. The Ovsynch treatment group received an injection (100 $\mu \mathrm{g}$ i.m.) of GnRH (Cystorelin, Merial Inc., Iselin, $\mathrm{NJ}$ ) at a random stage of the estrous cycle, followed $7 \mathrm{~d}$ later by $25 \mathrm{mg}$ of $\mathrm{PGF}_{2 \alpha}$ (Lutalyse, The Pharmacia-Upjohn Co., Kalamazoo, MI) and followed 2 d later with second GnRH $(100 \mu \mathrm{g})$ treatment. Timed AI was performed by farm personnel 16 to $18 \mathrm{~h}$ after second GnRH injection. In estrus detection group, cows that were not inseminated during the 21 -d experimental period were subsequently treated with the Ovsynch program. The schedule for ultrasound evaluations and blood sampling is shown in Figure 1. 
Pregnancy status was determined by using the ultrasound at 32 and $64 \mathrm{~d}$ post $\mathrm{AI}$ in the Ovsynch group and 28 to 34 and 58 to $64 \mathrm{~d}$ post $\mathrm{AI}$ in the estrus detection group. Visualization of a fluid-filled uterine horn with embryonic vesicles and a large CL (d 28 to 34) or the presence of a fetus ( $\mathrm{d} 58$ to 64 ) were used as positive indications of pregnancy. Pregnancy loss was calculated as the number of cows diagnosed nonpregnant at second pregnancy check, expressed as a percentage of cows diagnosed pregnant at first pregnancy check. Conception rate was calculated by the number of cows diagnosed pregnant, divided by the number of cows receiving AI. Pregnancy rate (PR) was calculated by the number of cows diagnosed pregnant to a breeding during the 21-d experimental period, divided by the number of cows in respective groups. Some cows $(n=12)$ were inseminated more than once during the 21-d experimental period in estrus detection group.

Blood samples were collected weekly into Vacutainer tubes (Becton Dickinson Co., Franklin Lakes, NJ) by coccygeal venipuncture from the beginning of the experiment to $11 \mathrm{~d}$ after AI. Blood was allowed to clot at $4{ }^{\circ} \mathrm{C}$ for $24 \mathrm{~h}$ and centrifuged at $1500 \times \mathrm{g}$ for $15 \mathrm{~min}$. Serum was poured into sample tubes and stored at $-20^{\circ} \mathrm{C}$ until assayed for progesterone.

Body condition scores were assessed by the same individual between d 47 and 53 using a scale from 1 to 5 , with $1=$ very thin and $5=$ obese.

\section{Hormone Assay}

Serum concentrations of progesterone were determined by a competitive ELISA as described previously (Rasmussen et al., 1996). Progesterone was extracted from serum using a double-extraction procedure as described (Rasmussen et al., 1996). Extraction efficiency ( $81 \pm 1.6 \%$; mean \pm SEM for 42 different ELISA plates) was evaluated by extracting charcoal-stripped serum containing known concentrations of progesterone. Extracted serum progesterone was reconstituted in 500$\mu \mathrm{l}$ volume of assay buffer $(0.04 M \mathrm{MOPS}, 0.12 \mathrm{M} \mathrm{NaCl}$, $0.01 M$ EDTA, $0.05 \%$ Tween $20,0.005 \%$ Chlorohexidinedigluconate, $0.1 \%$ gelatin, $\mathrm{pH} 7.4$ ) and directly used in the progesterone ELISA (Rasmussen et al., 1996). Coefficients of variation for within and between assays for progesterone were 4.1 and $8.6 \%$, respectively, using a quality control sample with $2.5 \mathrm{ng} / \mathrm{ml}$ of progesterone.

\section{Statistical Analysis}

Analyses of data were conducted using the Mixed Procedure of SAS (1998) with the one-way ANOVA model: $\mathbf{Y}_{i j}=\mu+\alpha_{i}+\varepsilon_{i j}$, where $\mathbf{i}=\operatorname{BCS}(1,2,3,4,5)$, or pregnancy status $(1,2), \mathrm{j}=$ cows $(1,2,3, \ldots \ldots .316)$, and $\varepsilon_{i j}=$ random error.
Student's $t$-test was used to compare days open (anovular vs. ovular). Days to breeding and pregnancy were evaluated by the Lifetest procedure of SAS. Body condition score vs. percentage anovular frequency slopes between primiparous and multiparous cows were analyzed by analysis of covariance comparing two models, a full model with separate slopes and a reduced model with common slopes. For the analysis of percentage of anovulation, the Arcsine square root transformation was used. The data with a binomial distribution were analyzed by Fisher's exact test.

\section{RESULTS AND DISCUSSION}

\section{Incidence and Classification of Anovulation}

Numerous previous studies have attempted to analyze the incidence of anovulation or follicular cysts in dairy herds. Our study appears to be the first to have used weekly ultrasound evaluations combined with circulating progesterone concentration to analyze and classify anovulation at the start of the breeding period in a commercial dairy herd. In this one commercial dairy herd, a total of $20.2 \%$ (64 of 316) of cows were anovular with no detectable luteal tissue by ultrasonography and low circulating progesterone concentrations at the first two evaluations done between 47 to $53 \mathrm{~d}$ postpartum and again $7 \mathrm{~d}$ (54 to $60 \mathrm{~d}$ postpartum) later. This rate of anovulation is comparable to previous studies using either rectal palpation or multiple determinations of circulating progesterone concentrations. In some older studies, the incidence of follicular cysts was determined by palpation of the ovary per rectum, and the incidence of follicular cysts ranged from 7 to $19 \%$ (see review Garverick, 1997). In earlier studies, smaller follicles ( $<25 \mathrm{~mm}$ in diameter) also were reported as follicular cysts if these follicles persisted until the next reproductive examination (Bartlett et al., 1986) or cows showed nymphomaniac estrous behavior even though follicle diameter was less than $25 \mathrm{~mm}$ (Hinze, 1959). Two recent studies from Florida dairy herds, reported an incidence of follicular cysts of 34 to $44 \%$ when cows were considered to have follicular cysts if no CL was detected, multiple large follicles ( $>20 \mathrm{~mm}$ in diameter) were present, and there was an absence of uterine tonicity based on one rectal palpation (Bartolome et al., 2000; 2002). Some recent studies have reported an incidence of anovulation in dairy cattle ranging from 18 to $29 \%$ based on serum progesterone concentrations in two blood samples taken 10 to $12 \mathrm{~d}$ apart (Cartmill et al., 2001; Moreira et al., 2001; Pursley et al., 2001). Several reports have indicated that these two methods (rectal palpation or serum progesterone concentration) are lower in accuracy than ultrasonography for classifica- 


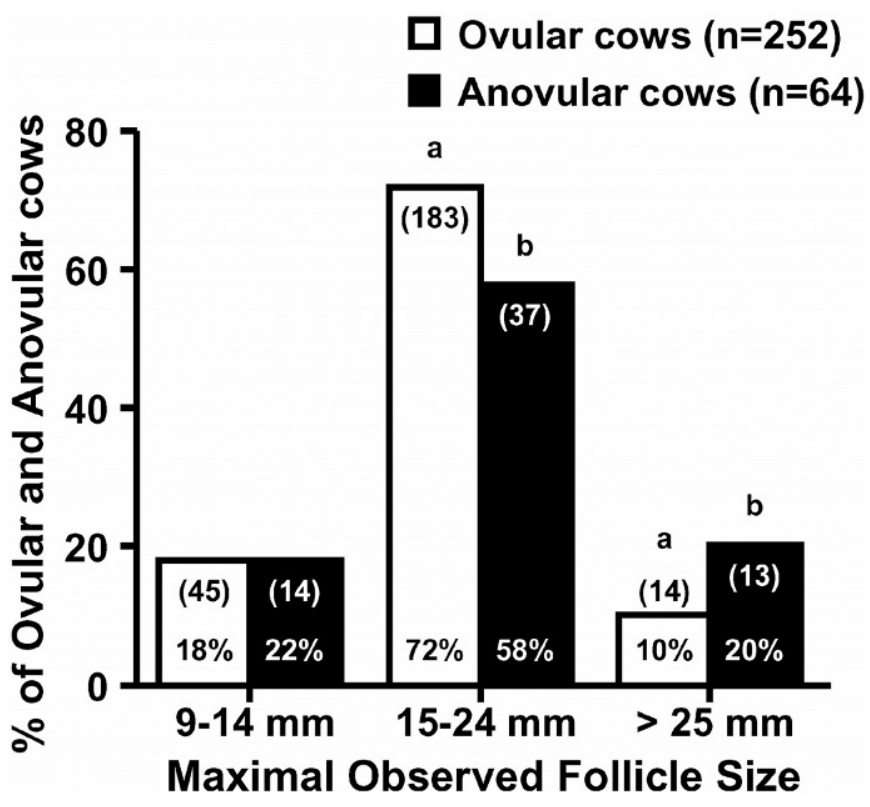

Figure 2. Distribution of maximal observed follicle size in ovular and anovular cows between 47 to 53 and 54 to $60 \mathrm{~d}$ postpartum. Different superscripts $(\mathrm{a}, \mathrm{b})$ denote significant differences $(P<0.05)$. The numbers of cows are shown in parentheses in each follicle size group.

tion of follicular cysts (Sprecher et al., 1988; Farin et al., 1992).

The multiple ultrasound evaluations used in this study allowed classification of cows that were anovular based on the maximal observed size of the anovular follicles. Previously, we have reported a method to classify anovular cows using maximal follicular diameters (Wiltbank et al., 2002). Selection of a dominant follicle occurs at about $9 \mathrm{~mm}$ in size, and this has been previously termed follicular deviation (Ginther et al., 1996). All anovular cows in this study had follicle diameters that exceeded $9 \mathrm{~mm}$. Thus, cows were divided by maximal follicular diameter into one of three groups: 1) deviation to ovular size (9 to $14 \mathrm{~mm}$ in diameter), 2) ovular size to cystic size (15 to $24 \mathrm{~mm}$ in diameter), or 3 ) cystic size ( $\geq 25 \mathrm{~mm}$ in diameter) (see review Wiltbank et al., 2002). These follicle sizes were the maximal size of the follicle detected with ultrasound scanning at two times, $7 \mathrm{~d}$ apart. As shown in Figure 2, most (78\%) anovular cows had large follicles ( $\geq 15 \mathrm{~mm}$ in diameter), while only $22 \%$ had smaller follicles (9 to $14 \mathrm{~mm}$ in diameter). Only $20 \%$ of anovular cows would be considered cystic (follicles $\geq 25 \mathrm{~mm}$ in diameter; $4 \%$ of all cows studied) with most (58\%) anovular cows having follicles larger than normal ovular size but not cystic size (15 to $24 \mathrm{~mm}$ in diameter). As shown in Figure 2, ovular cows had a similar incidence of smaller follicles (18\% with 9 to $14 \mathrm{~mm}$ maximal detected follicular diameter) but had a greater $(P<0.05)$ percentage of cows with 15 to $24 \mathrm{~mm}$ follicles and a lower $(P<0.05)$ percentage of cows with follicles $\geq 25 \mathrm{~mm}$ in diameter. Anovular conditions with smaller follicles (9 to $14 \mathrm{~mm}$ diameter) have been extensively studied. This type of anovular condition has been reported during the early postpartum period in lactating dairy and suckled beef cows (Williams, 1990; Schillo, 1992; Beam and Butler, 1997). The anovular condition with smaller follicles is characterized by enhanced negative feedback effects of estradiol on GnRH secretion from the hypothalamus (reviewed by Williams, 1990; Schillo, 1992). In contrast, cows with follicular cysts are characterized by very large follicles (Kesler and Garverick, 1982; Garverick, 1997) and an insensitivity of the hypothalamus to the positive feedback effects of estradiol (Refsal et al., 1987; Gümen et al., 2002; Gümen and Wiltbank, 2002). Intriguingly, this study shows that the majority of anovular cows (58\%) are classified as having follicles greater than normal ovular size but smaller than those that would be classified as follicular cysts. The physiology that underlies this anovulatory condition has not yet been determined.

A greater $(P<0.01)$ percentage of primiparous cows were anovular than multiparous cows ( 28 vs. $15 \%$, respectively) in this study. Older studies have generally reported a higher incidence of anovulation (follicular cysts) in multiparous than primiparous cows (Whitmore et al., 1974; Hackett and Batra, 1985; Bartlett et al., 1986). For example, follicular cysts were found in 5 to $5.7 \%$ of primiparous cows and in 16 to $18 \%$ of multiparous cows in two of these studies (Whitmore et al., 1974; Hackett and Batra, 1985). In the current study, anovular cows with follicles of $\geq 25 \mathrm{~mm}$ represented only $3.3 \%$ of the total group of primiparous cows and just $4.6 \%$ of all multiparous cows. Some recent studies seem to have similar incidence of anovulation in primiparous and multiparous cows (Bartolome et al., 2000, 2002). However, other recent studies (Cartmill et al., 2001; Moreira et al., 2001) agree with our results with a greater incidence of anovulation in primiparous cows than multiparous cows (for example, 37.3 vs. $15.7 \%$ in Moreira et al., 2001).

There was a strong negative correlation between incidence of anovulation and BCS (Figure 3A) similar to previous reports (Cartmill et al., 2001; Moreira et al., 2001). However, Moreira et al. (2001) reported a quadratic relationship; whereas, we found that the relationship was linear. Our determination of this linear relationship is only applicable in the narrow range that we felt provided meaningful data (2.25 to 3.25$)$. There were too few cows with BCS lower than 2.25 ( $\mathrm{n}=1$ anovular cow) to provide meaningful information. All cows greater than 3.25 BCS $(\mathrm{n}=11)$ were ovular, and, 


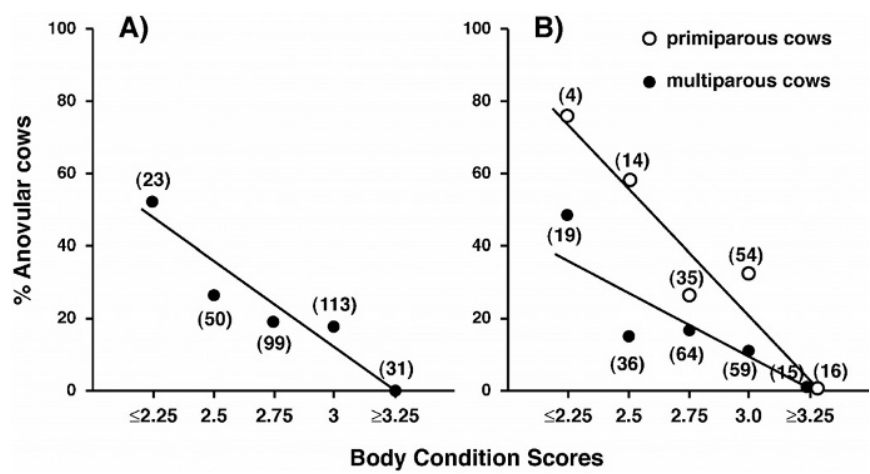

Figure 3. A) Percentage of all anovular (primiparous and multiparous) cows plotted by BCS at 47 to $53 \mathrm{~d}$ postpartum (PP). The only anovular cow with a BCS of 2.0 is included in BCS of 2.25. All cows with BCS greater than $3.25(\mathrm{n}=11)$ were cycling and are included in BCS of 3.25. The numbers of cows are shown in parentheses in each BCS group. There was a significant $(P<0.001)$ linear relationship between BCS and percentage of anovular cows: $\mathrm{y}=-44.9 \mathrm{x}+146.5$; $\mathrm{R}^{2}=0.75$. B) Percentage of anovular cows plotted by BCS at 47 to $53 \mathrm{~d} \mathrm{PP}$ in primiparous (open circles) and multiparous (close circles) cows. One multiparous anovular cow with a BCS of 2.0 is included in BCS of 2.25. All cows with BCS greater than 3.25 are included in BCS 3.25. Linear relationship between BCS and percentage of anovular cows was significant $(P<0.001)$ for both primiparous and multiparous cows. The primiparous cow model is: $\mathrm{y}=-70.1 \mathrm{x}+230.6$; $\mathrm{R}^{2}=0.91$. The multiparous cow model is: $\mathrm{y}=-39.4 \mathrm{x}+125.8 ; \mathrm{R}^{2}=$ 0.76 . Slopes between primiparous and multiparous cows tended to differ $(P=0.08)$.

therefore, we combined these cows into one group. In contrast, Moreira et al. (2001) analyzed cows with BCS ranging from 2.0 to 4.5 . Examination of their results between 2.25 to 3.25 indicates a linear relationship between BCS and frequency of anovulation. The relationship between incidence of anovulation and BCS tended to differ $(P=0.08)$ between primiparous and multiparous cows in our study (Figure 3B). The primiparous cows had a numerically greater incidence of anovulation than multiparous cows at each BCS up to 3.25. In addition, analysis of the maximal follicle diameter, as determined by ultrasound, and the BCS provided an interesting relationship. The anovular cows with smaller maximal follicle sizes had a lower average BCS than any other group of cows (Figure 4). In contrast, the cows with largest follicle size ( $\geq 25 \mathrm{~mm}$ in diameter) were not different in BCS from the ovular cows. Most $(79 \%, 11 / 14)$ anovular cows with small follicles (9 to 14 $\mathrm{mm}$ in diameter) had a BCS of $\leq 2.5$, whereas most anovular cows with larger follicles (15 to $24 \mathrm{~mm} ; 74 \%$; $28 / 38$ ) or cystic size follicles ( $\geq 25 \mathrm{~mm} ; 75 \%$; $9 / 12$ ) had a BCS of $\geq 2.75$. Ovular cows had no difference in BCS among the three follicular size groups.

\section{Relationship Between Milk Production and Anovular Follicle Size}

The relationship between milk production and follicular cysts has been examined in previous studies with

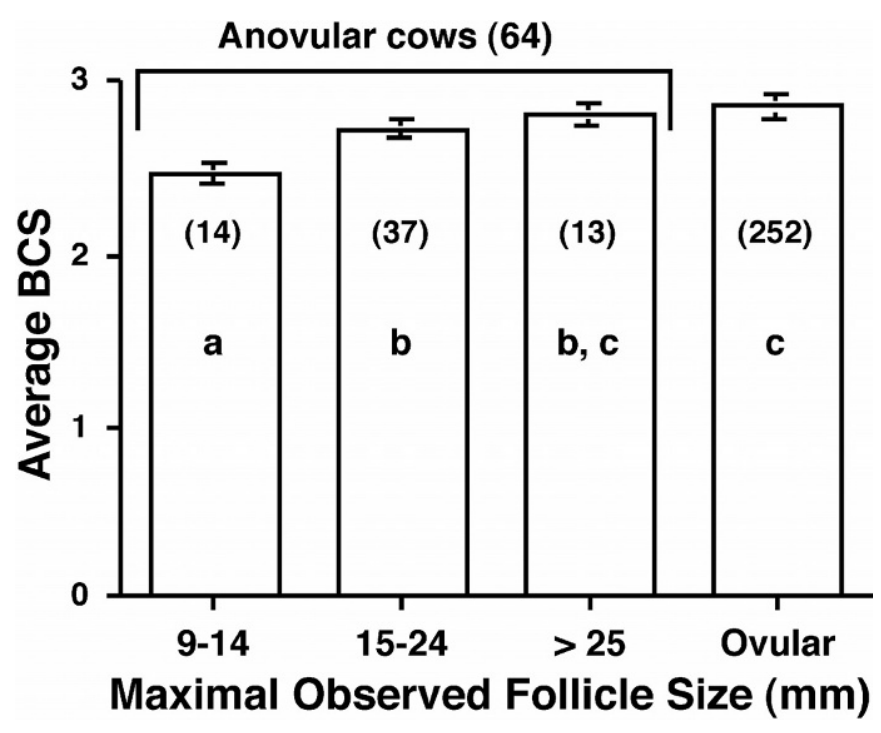

Figure 4. Body condition score (BCS) plotted by maximal observed follicle size categories in anovular cows between 47 to 53 and 54 to $60 \mathrm{~d}$ postpartum. There was no difference in BCS between ovular cows with different follicle sizes and, therefore, all ovular cows are combined into one group. Bars with different letters (a, b, c) differ $(P<0.05)$. The numbers of cows are shown in parentheses in each follicle size group.

inconsistent findings. Some studies found no difference in incidence of follicular cysts between high and low producing dairy cows (Wiltbank et al., 1953; Whitmore et al., 1974; Nanda et al., 1989). Others studies reported that cystic cows produced more milk than their herd mates (Bartlett et al., 1986; Heuer et al., 1999; Fleischer et al., 2001). In our study, we analyzed the relationship between milk production (between 49 to $56 \mathrm{~d}$ postpartum) in anovular vs. ovular cows. There was a significant effect of parity on milk production; therefore, all data from primiparous cows were analyzed separately from multiparous cows. Analysis of all cows indicated a tendency for greater milk production $(P=0.09)$ in ovular primiparous cows vs. anovular primiparous cows, but no such difference was apparent in multiparous cows (Table 1). Intriguingly, the maximal follicle size appeared to be related to milk production in ovular and anovular primiparous cows and in anovular multiparous cows but not in ovular multiparous cows (Table 1). These effects were primarily the result of low milk production in cows with the smallest follicular size (9 to $14 \mathrm{~mm}$ in diameter). In particular, anovular cows with a smaller maximal follicle size had lower milk production than anovular cows with larger follicles. To our knowledge, this is the first study that has reported a relationship between milk production and follicle size. Confirmation of this relationship and determination of mechanisms that may underlie this relationship will require further research. 
Table 1. Comparison of milk production (average for $\mathrm{d} 49$ to $56 \mathrm{in} \mathrm{kg} / \mathrm{d}$ ) between primiparous and multiparous cows separated according to follicle size and ovulation status.

\begin{tabular}{|c|c|c|c|c|c|c|}
\hline \multirow{2}{*}{$\begin{array}{l}\text { Maximal } \\
\text { follicle size }\end{array}$} & \multicolumn{3}{|c|}{ Primiparous cows } & \multicolumn{3}{|c|}{ Multiparous cows } \\
\hline & Ovular & Anovular & $P$-value & Ovular & Anovular & $P$-value \\
\hline 9 to $14 \mathrm{~mm}$ & $\begin{array}{l}28.3 \pm 1.1 \\
(\mathrm{n}=23)\end{array}$ & $\begin{array}{l}23.0 \pm 2.0 \\
(\mathrm{n}=7)\end{array}$ & 0.03 & $\begin{array}{l}42.2 \pm 1.6 \\
(\mathrm{n}=22)\end{array}$ & $\begin{array}{l}32.4 \pm 2.8^{\mathrm{a}} \\
(\mathrm{n}=7)\end{array}$ & 0.006 \\
\hline 15 to $24 \mathrm{~mm}$ & $\begin{array}{l}31.7 \pm 0.8 \\
(\mathrm{n}=61)\end{array}$ & $\begin{array}{l}29.7 \pm 1.4 \\
(\mathrm{n}=23)\end{array}$ & 0.23 & $\begin{array}{l}39.6 \pm 0.8 \\
(\mathrm{n}=122)\end{array}$ & $\begin{array}{l}42.1 \pm 2.4^{\mathrm{b}} \\
(\mathrm{n}=14)\end{array}$ & 0.323 \\
\hline$>25 \mathrm{~mm}$ & $\begin{array}{l}32.5 \pm 2.7 \\
(\mathrm{n}=4)\end{array}$ & $\begin{array}{l}32.1 \pm 2.7 \\
(\mathrm{n}=4)\end{array}$ & 0.93 & $\begin{array}{l}41.5 \pm 1.8 \\
(\mathrm{n}=20)\end{array}$ & $\begin{array}{l}43.5 \pm 2.8^{\mathrm{b}} \\
(\mathrm{n}=9)\end{array}$ & 0.543 \\
\hline$P$-value & 0.06 & 0.08 & & 0.32 & 0.05 & \\
\hline Total & $\begin{array}{l}30.8 \pm 0.7 \\
(\mathrm{n}=88)\end{array}$ & $\begin{array}{l}28.6 \pm 1.1 \\
(\mathrm{n}=34)\end{array}$ & 0.09 & $\begin{array}{l}40.2 \pm 0.7 \\
(\mathrm{n}=164)\end{array}$ & $\begin{array}{l}40.3 \pm 1.6 \\
(\mathrm{n}=30)\end{array}$ & 0.95 \\
\hline
\end{tabular}

${ }^{\mathrm{a}, \mathrm{b}}$ Values with different superscripts within columns differ $(P<0.05)$.

\section{Response of Ovular vs. Anovular Cows During the Experimental Period}

We analyzed ovulation rate, breeding errors, days open, and double ovulation rate in both ovular and anovular cows during the experimental period. Percentage of cows ovulating to GnRH (Ovsynch group) and spontaneous ovulation (estrus detection group) was determined by ultrasonography and serum progesterone concentration in this study.

Ovsynch group. Percentage of cows ovulating to the first GnRH injection of Ovsynch was greater $(P<0.005)$ in anovular $(88 \%, 29 / 33)$ than in ovular $(62 \%, 72 / 117)$ cows (Table 2). The efficacy of GnRH for treatment of follicular cysts in cows has been examined by several studies in the late 1970s. These studies reported that 72 to $90 \%$ of cows with follicular cysts responded to a GnRH treatment based on an increase in serum progesterone after GnRH (see review Kesler and Garverick, 1982). In a recent study, 92\% (799/869) of cystic cows had detectable luteal tissue after GnRH (Hooijer et al., 1999). We also observed luteal tissue in a high percentage (88\%) of anovular cows following $\mathrm{GnRH}$ treatment. Thus, most of the anovular cows responded to the first GnRH treatment as determined by detectable luteal tissue and increased serum progesterone concentration. In contrast, the lower percentage of ovular cows re- sponding to the first GnRH in our study $(62 \%)$ is similar to the ovulation rate $(64 \%)$ reported after treatment of ovular cows at a random stage of the estrous cycle (Vasconcelos et al., 1999). Ovulation rate was reported to be greater in response to second GnRH than first GnRH using Ovsynch (Vasconcelos et al., 1999). Most ovular (97\%; 114/117) and anovular (94\%; 31/33) cows ovulated to the second GnRH injection in our study (Table 2). In two recent studies, ovulation to second GnRH was determined by either ultrasound (Vasconcelos et al., 1999) or serum progesterone concentration (Moreira et al., 2001). Ovulation rate in response to the second GnRH of Ovsynch was reported between 87\% (Vasconcelos et al., 1999) and 91\% (Moreira et al., 2001) of cycling cows. Synchronization rate was defined by two criteria in the present study, regression of CL to $\mathrm{PGF}_{2 \alpha}$ injection and ovulation of the dominant follicle to the second GnRH injection. Synchronization rate has been reported to be between 82 to $87 \%$ in cycling lactating dairy cows in previous studies (Fricke and Wiltbank, 1999; Vasconcelos et al., 1999; Pursley et al., 2001). We observed a similar synchronization rate in ovular (92\%) and anovular (91\%) cows (Table 2). However, our finding of a high synchronization rate in anovular cows $(91 \%)$ contrasts with previous reports of $51 \%$ (Cartmill et al., 2001), and 73\% (Fricke and Wiltbank, 1999).

Table 2. Comparison of the response of ovular $(n=117)$ and anovular $(n=33)$ cows assigned to the Ovsynch protocol.

\begin{tabular}{lccl}
\hline & Ovular cows & Anovular cows & $P$-value \\
\hline Ovulation to first GnRH injection $_{\text {No CL regression to } \mathrm{PGF}_{2 \alpha} \text { injection }}$ & $62 \%(72 / 117)$ & $88 \%(29 / 33)$ & 0.004 \\
Ovulation to second GnRH injection $^{1}$ & $5 \%(6 / 117)$ & $3 \%(1 / 33)$ & 0.614 \\
Synchronization rate $^{1}$ & $97 \%(114 / 117)$ & $94 \%(31 / 33)$ & 0.323 \\
Double ovulation to first GnRH injection & $92 \%(108 / 117)$ & $91 \%(30 / 33)$ & 0.794 \\
Double ovulation to second GnRH injection & $4 \%(3 / 72)$ & $41 \%(12 / 29)$ & 0.0001 \\
Cows with a short luteal phase $(<11$ d) after Ovsynch & $12 \%(14 / 114)$ & $13 \%(4 / 31)$ & 0.926 \\
\hline
\end{tabular}

${ }^{1}$ Synchronization rate $=$ regression of CL in response to prostaglandin and ovulation of dominant follicle in response to second GnRH. 
Table 3. Comparison of ovular $(n=135)$ and anovular $(n=31)$ cows assigned to the estrus detection group in expression of estrus during the 21-d experimental period.

\begin{tabular}{lcll}
\hline & Ovular cows & Anovular cows & $P$-value \\
\hline Inseminated during 21 d & $72 \%(97 / 135)$ & $29 \%(9 / 31)$ & 0.0001 \\
Inseminated at incorrect time(no ovulation) & $5 \%(5 / 97)$ & $78 \%(7 / 9)$ & 0.0001 \\
Inseminated without ovulation in absence of CL & $0 \%(0 / 5)$ & $86 \%(6 / 7)$ & 0.003 \\
Inseminated without ovulation in the presence of CL & $100 \%(5 / 5)$ & $14 \%(1 / 7)$ & 0.003 \\
Cows that did not ovulate during 21-d period & $11 \%(15 / 135)$ & $58 \%(18 / 31)$ & 0.0001 \\
Persistent CL during 21-d period & $4 \%(6 / 135)$ & $\ldots$ & $\ldots$ \\
Double ovulation during 21-d period & $16 \%(19 / 120)$ & $38 \%(5 / 13)$ & 0.044 \\
Cows that ovulated but not detected in estrus & $19 \%(23 / 120)$ & $85 \%(11 / 13)$ & 0.0001 \\
\hline
\end{tabular}

Estrus detection group. Spontaneous ovulation was observed in $42 \%$ (13 of 31 ) of the anovular cows in the estrus detection group during the 21-d treatment period (Table 3). Similar spontaneous recovery (48 to $69 \%)$ from follicular cysts was reported by Morrow et al. (1966) and Whitmore et al. (1974). In our study, 29\% (9/31) of anovular cows were inseminated, but only two of these nine cows were inseminated at a time near ovulation (ovulation detected at next ultrasound examination). The other seven cows were inseminated either without ovulation in the absence (6/7) or presence (1/ 7 ) of a CL (Table 3). In contrast, 89\% (120/135) of the ovular cows had a spontaneous ovulation during the 21 -d breeding period with $72 \%(97 / 135)$ receiving $\mathrm{AI}$ in the estrous detection group. Among ovular and anovular cows together, $63.8 \%$ of 166 cows assigned to estrus detection were detected in estrous and inseminated within $21 \mathrm{~d}$. The estrus detection rate during the treatment period in this herd was unexpectedly high compared with the $45 \%$ estrus detection rate recently reported using DHI records (Washburn et al., 2002). In addition, the estrus detection accuracy was surprisingly high in our study, with only 5\% (5/97) of ovular cows inseminated incorrectly (Table 3). Breeding errors using estrus detection have been studied by several investigators using milk progesterone concentrations with reports of errors in time of AI ranging from 3.3 to $18.7 \%$. (Pennington et al., 1985; Nebel et al., 1987; Cavestany and Galina, 2001). For example, a recent study showed substantial variation among herds (range of 4.5 to $30.5 \%$ ) in percentages of cows that were inseminated when not in estrus (Cavestany and Galina, 2001).

In our study, there was a surprisingly high percentage $(90 \%, 228 / 252)$ of ovular cows that had a CL at first scan (47 to $53 \mathrm{~d}$ postpartum), and $30 \%$ (69/228) of these cows had two CL at the time of this first ultrasound examination. Double ovulation rate was lower $(P<$ $0.0001)$ in ovular $(4 \%, 3 / 72)$ than anovular $(41 \%, 12 /$ 29) cows after the first GnRH injection of the Ovsynch program (Table 2). However, there was no difference at the second GnRH injection of Ovsynch between ovular $(12 \%, 14 / 114)$ and anovular $(13 \%, 4 / 31)$ cows (Table 2$)$.
A similar double ovulation rate (14.1\%) was previously reported after the second GnRH injection of Ovsynch (Fricke and Wiltbank, 1999). In the estrus detection group, double ovulation rate was also lower $(P<0.05)$ in ovular $(16 \%, 19 / 120)$ than anovular $(38 \%, 5 / 13)$ cows during the 21-d period of the study (Table 3). Double ovulation in two older studies was determined by the presence of two or more palpable CL by rectal examination, and the incidence was between 5.4 and $13.1 \%$ (Kidder et al., 1952; Labhsetwar et al., 1963). One much older study reported a greater incidence of twinning in cows that conceived upon recovery from the cystic condition (Clapp, 1934). It has also been reported that cystic cows have more than a three times greater incidence of double ovulation than ovular cows (12.9 vs. 4.2\%) (Labhsetwar et al., 1963).

\section{Comparison of Ovsynch vs. Estrus Detection Group}

Breeding in the estrus detection group began $10 \mathrm{~d}$ before breeding in the Ovsynch group so that, on average, cows were inseminated at the same time postpartum albeit all cows in the Ovsynch group were inseminated and only those observed in estrus were inseminated in the other group (Table 4). Although average days to first breeding were similar, the distribution of time at first AI between the two groups was different $(P<0.05$; Figure 5A).

Conception rate, as determined by the pregnancy diagnosis at 58 to $64 \mathrm{~d}$ after AI, was similar in the Ovsynch and estrus detection groups for ovular (32\% [37/ 117], $35 \%$ [34/97], respectively) and anovular (9\% [3/ 33 ], 11\% [1/9], respectively) cows (Table 4). Conception rate using the Ovsynch program was similar in this experiment compared with other studies. In other studies, conception rates have ranged between 31 to $42 \%$ in ovular cows following the Ovsynch protocol (Pursley et al., 1997a; 1997b; Fricke and Wiltbank, 1999; Tenhagen et al., 2001; Moreira et al., 2001; Pursley et al., 2001). However, conception rate in anovular cows following Ovsynch was surprisingly low (9\%) in our study 
Table 4. Comparison of ovular and anovular cows in the estrus detection vs. Ovsynch group.

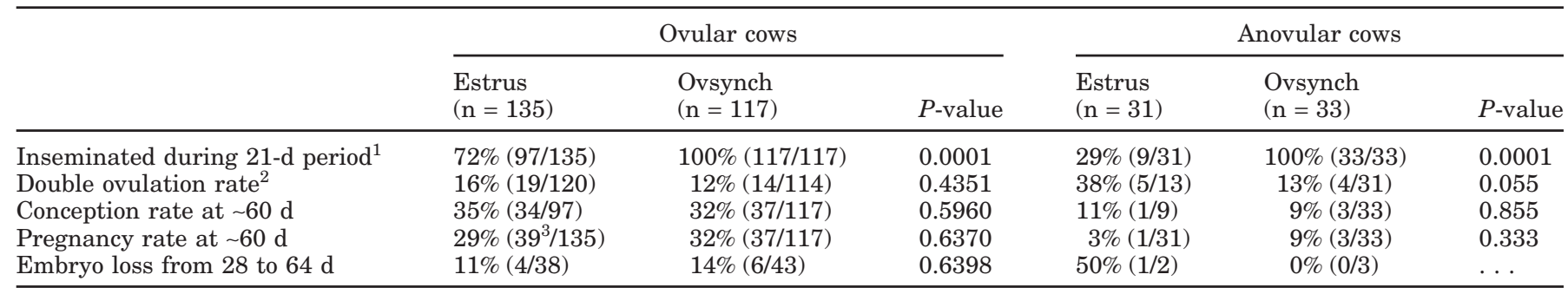

${ }^{1}$ All Ovsynch cows were inseminated by appointment, whereas only cows observed in estrus were inseminated in the estrus detection subgroups.

${ }^{2}$ Double ovulation was determined at first detected spontaneous ovulation during 21-d experimental period in the estrus detection group or at the second GnRH injection of the Ovsynch group.

${ }^{3}$ Five cows in this group received two inseminations within a $21-d$ period.

compared with results reported in previous studies (between 24 to 37\%) in anovular cows following Ovsynch (Fricke and Wiltbank, 1999; Bartolome et al., 2000; Pursley et al., 2001). We cannot adequately explain this difference in results. Anovular cows in the current study were earlier postpartum than in other studies that used cows that were nonpregnant at any time postpartum (Fricke and Wiltbank, 1999; Bartolome et al., 2000; Pursley et al., 2001). Stage of lactation has been shown to affect CR, with cows greater than $76 \mathrm{~d}$ postpartum having greater CR (43\%) than cows that were between 60 to $75 \mathrm{~d}$ postpartum (26\%) (Pursley et al., 1997b). Interestingly, the anovular cows in the estrus detection group were treated with the Ovsynch program after the 21-d experimental period and a conception rate of $27.7 \%$ (5/18) was found after Ovsynch at that time. In addition, the lower BCS in anovular than ovular cows may have contributed to the lower CR. Moreira et al. (2000) reported that CR was lower for cows with lower BCS. Santos et al. (2001) reported that cows with moderate BCS at the time of AI had greater $(P<0.001)$ CR rates than cows with low body condition (49 vs. $34 \%)$. Ambrose et al. (1999) reported a 37\% increase in CR for every unit increase in BCS in heat-stressed

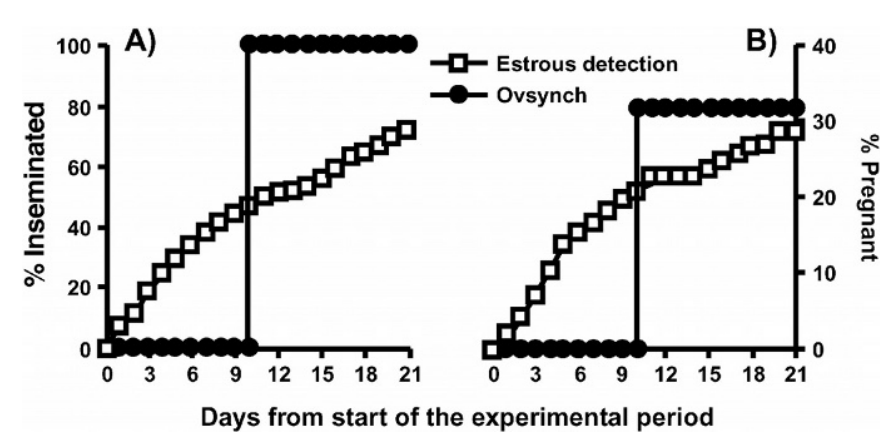

Figure 5. Percentage of inseminated (A) and pregnant (B) ovular cows in Ovsynch and estrous detection groups during 21-d experimental period. lactating dairy cows after timed embryo transfer. Thus, it may be advantageous to wait until a later time postpartum before breeding anovular cows to allow an increased BCS and possible spontaneous return to cyclicity. Nevertheless, determination of the optimal time postpartum for insemination of anovular cows will obviously require studies that are specifically designed to address this subject. A further observation from our study that may be relevant in understanding the lower $\mathrm{CR}$ in anovular cows was the greater incidence of premature luteal regression (23 vs. 6\%) in anovular than ovular cows (Table 2). This observation suggests that the uterus may not be properly prepared for pregnancy resulting in premature secretion of $\mathrm{PGF}_{2 \alpha}$ from the uterus and premature luteal regression.

Pregnancy diagnosis was also done at 28 to $34 \mathrm{~d}$ after AI to determine the rate of pregnancy loss between $\sim 30$ and $\sim 60 \mathrm{~d}$ postpartum. Pregnancy loss was high during this period but was not different between Ovsynch $(14 \%, 6 / 43)$ and estrus detection group $(11 \%, 4 / 38)$ in ovular cows (Table 4). Previous studies also showed high (9.3 to $16.8 \%$ ) pregnancy losses between 28 to 56 d after AI (Vasconcelos et al., 1997; Santos et al., 2001). We did not compare pregnancy loss for anovular cows because of the low number of pregnancies.

The percentage of cows that became pregnant during the 21-d experimental period (pregnancy rate) was not different between Ovsynch and estrus detection groups (Table 4), but the timing of pregnancy during the experimental period differed $(P<0.05)$ between these two groups (Figure 5B). It should be noted that some cows $(\mathrm{n}=12)$ in the estrus detection group were inseminated a second time and became pregnant (5/12) during the $21-d$ period. These pregnancies are included in the pregnancy rate for the estrus detection group.

This study was not designed to compare days open between groups because comparisons were confounded by the aggressive use of Ovsynch after the treatment period in the estrus detection group. Nevertheless, days 


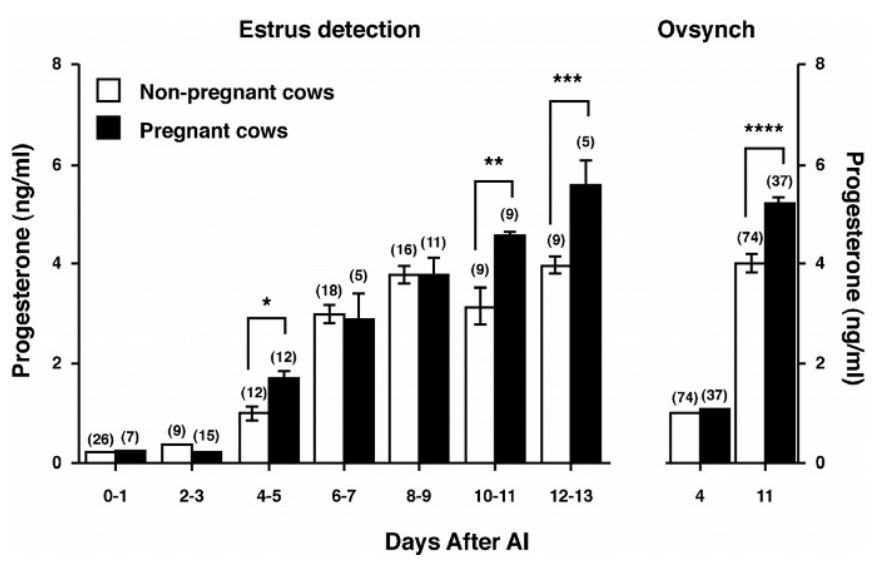

Figure 6. Serum progesterone concentrations of pregnant and nonpregnant cows in estrus detection and Ovsynch groups on different days after artificial insemination (AI) in ovular cows. The numbers of cows are shown in parentheses in each group. $* P=0.07,{ }^{* *} P<$ $0.05, * * * P<0.01, * * * * P<0.005$.

open were lower $(P<0.01)$ in ovular $(120 \mathrm{~d})$ than anovular (151 d) cows, although there was no difference between treatments (Ovsynch, [126 and $144 \mathrm{~d}$ ] vs. estrus detection, [114 and $156 \mathrm{~d}$ ]) in ovular or anovular cows, respectively. A previous study (Pursley et al., 1997a) has shown a substantial reduction in days open when Ovsynch is aggressively used throughout the full lactation compared with cows bred by normal reproductive management without Ovsynch.

Serum progesterone concentrations were not different between pregnant and nonpregnant cows in ovular cows $4 \mathrm{~d}$ after AI in the Ovsynch group (Figure 6). However, at $11 \mathrm{~d}$ after AI, serum progesterone concentrations were greater $(P<0.005)$ in pregnant than nonpregnant cows (Figure 6). In the estrus detection group, serum progesterone concentrations tended to be greater $(P=0.07)$ in pregnant than nonpregnant cows 4 to $5 \mathrm{~d}$ after AI, but the difference was significant $(P<0.05)$ at 10 to $11 \mathrm{~d}$ after AI (Figure 6). In contrast to our findings, no differences were found in progesterone concentrations after AI between pregnant and nonpregnant cows by Taylor and Rajamahendran (1991). However, other studies found a difference in circulating progesterone between pregnant vs. nonpregnant cows after AI. A higher concentration of progesterone as early as d 6 after AI has been reported in naturally ovulating pregnant cows (Henricks et al., 1971; Ahmad et al., 1996). Henricks and Dickey (1970) and Lukaszewska and Hansel (1980) reported that pregnant cows had a greater serum progesterone concentration than nonpregnant cows as early as d 10 of pregnancy. A delay in the postovulatory rise of progesterone was observed in nonpregnant vs. pregnant cows (Mann and Lamming, 2001). Our descriptive study can obviously not distinguish whether these pregnancy-associated differences in circulating progesterone are of physiological relevance. Some studies have suggested that the increase in circulating progesterone may be critical for optimal embryo development (Garrett et al., 1988; Kleemann et al., 1994; Mann and Lamming, 2001). Alternatively, some authors have suggested that the embryo secretes luteotrophic substances (Thibodeaux et al., 1994) that could increase circulating progesterone in pregnant cows, although no luteotrophic effect of the embryo was observed by Shelton et al. (1990).

\section{CONCLUSIONS AND PRACTICAL IMPLICATIONS}

This study used weekly ultrasound and progesterone evaluations to provide further insight into anovulation in commercial dairy cattle. Anovulation was a substantial reproductive problem in high-producing dairy cows with $20 \%$ of dairy cows not ovulating by $\sim 60 \mathrm{~d}$ postpartum. The use of ultrasound allowed classification of these anovular cows by maximal follicular size showing that most of the anovular cows have follicles greater than the normal ovulatory size but less than cystic size. Such anovular follicles may be difficult to diagnose with a single palpation per rectum. Programs to identify and treat anovular cows could use BCS because cows with lower BCS had a greater likelihood to be anovular, and cows with the smallest size of anovular follicles had the lowest average BCS. The Ovsynch program was found to effectively synchronize ovulation in both anovular and ovular cows. However, anovular cows had lower CR and PR than ovular cows, and Ovsynch did not improve the reproductive performance of anovular cows. Obviously, these intriguing results from a single commercial dairy herd need to be repeated to confirm their applicability to other herds in other environments. Nevertheless, it appears that synchronization programs, other than Ovsynch, need to be developed to improve reproductive performance of anovular cows.

\section{ACKNOWLEDGMENTS}

A. Gümen was supported by a fellowship from the Ministry of National Education of Turkey. The authors thank Jerry Gaska (DVM) for his assistance in conducting this experiment. We also thank Nehls Dairy Farm (Juneau, WI) for the use of their herd and facilities. Support was also provided by the Wisconsin State Experiment Station and USDA grant No. 2000-2276.

\section{REFERENCES}

Ahmad, N., S. W. Beam, W. R. Butler, D. R. Deaver, R. T. Duby, D. R. Elder, J. E. Fortune, L. C. Griel, L. S. Jones, R. A. Milvae, J. L. Pate, I. Revah, D. T. Schreiber, D. H. Townson, P. C. W. Tsang, 
and E. K. Inskeep. 1996. Cooperative Regional Research Project. NE-161. Relationship of fertility to patterns of ovarian follicular development and associated hormonal profiles in dairy cows and heifers. J. Anim. Sci. 74:1943-1952.

Ambrose, J. D., M. Drost, R. L. Monson, J. J. Rutledge, M. L LeibfriedRutledge, M. J. Thatcher, T. Kassa, M. Binelli, P. J. Hansen, P. J. Vhenoweth, and W. W. Thatcher. 1999. Efficacy of timed embryo transfer with fresh and frozen in vitro produced embryos to increase pregnancy rates in heat-stressed dairy cattle. J. Dairy Sci. 82:2369-2376.

Bartlett, P. C., P. K. Ngategize, J. B. Kaneene, J. H. Kirik, S. M, Anderson, and E. C. Mather. 1986. Cystic follicular disease in Michigan Holstein-Friesian cattle: Incidence, descriptive epidemiology and economic impact. Prev. Vet. Med. 4:15-33.

Bartolome, J. A., L. F. Archbald, P. Morresey, J. Hernandez, T. Tran, D. Kelbert, K. Long, C. A. Risco, and W. W. Thatcher. 2000. Comparison of synchronization of ovulation and induction of estrus as therapeutic strategies for bovine ovarian cysts in the dairy cow. Theriogenology 53:815-825.

Bartolome, J. A., J. Hernandez, A. Landaeta, A. Lelleman, P. Sheerin, C. A. Risco, and L. F. Archbald. 2002. The effect of interval from day of administration of bovine somatropin (bST) to synchronization of ovulation and timed-insemination on conception rate of dairy cows with and without ovarian cysts. Theriogenology 57:1293-1301

Beam, S. W., and W. R. Butler. 1997. Energy balance and ovarian follicle development prior to the first ovulation postpartum in dairy cows receiving three levels of dietary fat. Biol. Reprod. 56:133-142.

Cartmill, J. A., S. Z. El-Zarkouny, B. A. Hensley, G. C. Lamb, and J. S. Stevenson. 2001. Stage of cycle, incidence, and timing of ovulation, and pregnancy rates in dairy cattle after three timed breeding protocols. J. Dairy Sci. 84:1051-1059.

Cavestany, D., and C. S. Galina. 2001. Evaluation of an artificial insemination programme in a seasonal breeding dairy system through milk progesterone. Reprod. Dom. Anim. 36:79-84.

Clapp, H. 1934. Cystic ovaries and twinning in Holsteins. Cornell Vet. 24:309-324.

Cordoba, M. C., and P. M. Fricke. 2002. Initiation of the breeding season in a grazing-based dairy by synchronization of ovulation. J. Dairy Sci. 85:1752-1763.

Farin, P. W., R. S. Youngquist, J. R. Parfet, and H. A. Garverick. 1992. Diagnosis of luteal and follicular ovarian cysts by palpation per rectum and linear-array ultrasonography in dairy cows. JAVMA 200:1085-1089.

Fleischer, P., M. Metzner, M. Beyerbach, M. Hoedemaker, and W. Klee. 2001. The relationship between milk yield and the incidence of some diseases in dairy cows. J. Dairy Sci. 84:2025-2035.

Fricke, P. M., and M. C. Wiltbank. 1999. Effect of milk production on the incidence of double ovulation in dairy cows. Theriogenology $52: 1133-1143$

Garrett, J. E., R. D. Geisert, M. T. Zavy, and G. L. Morgan. 1988. Evidence for maternal regulation of early conceptus growth and development in beef cattle. J. Reprod. Fertil. 84:437-446.

Garverick, H. A. 1997. Ovarian follicular cysts in dairy cows. J. Dairy Sci. 80:995-1004.

Ginther, O. J., M. C. Wiltbank, P. M. Fricke, J. R. Gibbons, and K. Kot. 1996. Selection of the dominant follicle in cattle. Biol. Reprod. 55:1187-1194.

Gümen, A., and M. C. Wiltbank. 2002. An alteration in the hypothalamic action of estradiol due to lack of progesterone exposure can cause follicular cysts in cattle. Biol. Reprod. 66:1689-1695.

Gümen, A., R. Sartori, F. M. J. Costa, and M. C. Wiltbank. 2002. A $\mathrm{GnRH} / \mathrm{LH}$ surge without subsequent progesterone exposure can induce development of follicular cysts. J. Dairy Sci. 85:43-50.

Hackett, A. J., and T. R. Batra. 1985. The incidence of cystic ovaries in dairy cattle housed in a total confinement system. Can. J. Comp. Med. 49:55-57.

Henricks, D. M., and J. F. Dickey. 1970. Serum luteinizing hormone and plasma progesterone levels during the estrous cycle and early pregnancy in cows. Biol. Reprod. 2:346-351.
Henricks, D. M., D. R. Lamond, J. R. Hill, and J. F. Dickey. 1971. Plasma progesterone concentrations before mating and in early pregnancy in the beef heifer. J. Anim. Sci. 33:450-454.

Heuer, C., Y. N. Schukken, and P. Dobbelaar. 1999. Postpartum body condition score and results from the first test day milk as predictors of disease, fertility, yield, and culling in commercial dairy herds. J. Dairy Sci. 82:295-304.

Hinze, P. M. 1959. Diagnosis and treatment of nonspecific infertility in the dairy cow. JAVMA 134:302-307.

Hooijer, G. A., K. Frankena, M. M. H. Valks, and M. Schuring. 1999. Treatment of cystic ovarian disease in dairy cows with gonadotropin-releasing hormone: A field study. Vet. Q. 21:33-37.

Kesler, D. J., and H. A. Garverick. 1982. Ovarian cysts in dairy cattle: A review. J. Anim. Sci. 55:1147-1159.

Kidder, H. E., G. R. Barrett, and L. E. Casida. 1952. A study of ovulations in six families of Holstein-Friesians. J. Dairy Sci. 35:436-444.

Kleemann, D. O., S. K. Walker, and R. F. Seamark. 1994. Enhanced fetal growth in sheep administered progesterone during the first three days of pregnancy. J. Reprod. Fertil. 102:411-417.

Labhsetwar, A. P., W. J. Tyler, and L. E. Casida. 1963. Analysis of variation in some factors affecting multiple ovulations in Holstein cattle. J. Dairy Sci. 46:840-842.

Lukaszewska, J., and W. Hansel. 1980. Corpus luteum maintenance during early pregnancy in the cow. J. Reprod. Fertil. 59:485-493.

Mann, G. E., and G. E. Lamming. 2001. Relationship between maternal endocrine environment, early embryo development and inhibition of the luteolytic mechanism in cows. Reproduction 121:175-180.

Moreira, F., C. Orlandi, C. A. Risco, R. Mattos, F. Lopes, and W. W. Thatcher. 2001. Effects of presynchronization and bovine somatotropin on pregnancy rates to a timed artificial insemination protocol in lactating dairy cows. J. Dairy Sci. 84:1646-1659.

Moreira, F., C. Risco, M. F. A. Pires, J. D. Ambrose, M. Drost, M. DeLorenzo, and W. W. Thatcher. 2000. Effect of body condition on reproductive efficiency of lactating dairy cows receiving a timed insemination. Theriogenology 53:1305-1319.

Morrow, D. A., S. J. Roberts, K. McEntee, and H. G. Gray. 1966. Postpartum ovarian activity and uterine involution in dairy cattle. JAVMA 149:1596-1609.

Nakao, T., A. Sugihashi, N. Saga, N. Tsunoda, and K. Kawata. 1983 Use of milk progesterone enzyme immunoassay for differential diagnosis of follicular cyst, luteal cyst, and cystic corpus luteum in cows. Am. J. Vet. Res. 44:888-890.

Nanda, A. S., W. R. Ward, and H. Dobson. 1989. The relationship between milk yield and cystic ovarian disease in cattle. Br. Vet. J. 145:39-45.

Nebel, R. L., W. D. Whittier, B. G. Cassell, and J. H. Britt. 1987. Comparison of on-farm and laboratory milk progesterone assays for identifying errors in estrus detection and diagnosis of pregnancy. J. Dairy Sci. 70:1471-1476.

Opsomer, G., M. Coryn, H. Deluyker, and A. de Kruif. 1998. An analysis of ovarian dysfunction in high yielding dairy cows after calving based on progesterone profiles. Reprod. Domest. Anim. 33:193-204.

Pennington, J. A., L. H. Schultz, and W. F. Hoffman. 1985. Comparison of pregnancy diagnosis by milk progesterone on day 21 and day 24 postbreeding: Field study in dairy cattle. J. Dairy Sci. 68:2740-2745.

Pursley, J. R., P. M. Fricke, H. A. Garverick, D. J. Kesler, J. S. Ottobre, J. S. Stevenson, and M. C. Wiltbank. 2001. Improved fertility in noncycling lactating dairy cows treated with exogenous progesterone during Ovsynch. J. Dairy Sci. 83(Suppl. 1):1563. (Abstr.)

Pursley, J. R., M. R. Kosorok, and M. C. Wiltbank. 1997a. Reproductive management of lactating dairy cows using synchronization of ovulation. J. Dairy Sci. 80:301-306.

Pursley, J. R., M. O. Mee, and M. C. Wiltbank. 1995. Synchronization of ovulation in dairy cows using $\mathrm{PGF}_{2 \alpha}$ and $\mathrm{GnRH}$. Theriogenology 44:915-923

Pursley, J. R., M. C. Wiltbank, J. S. Stevenson, J. S. Ottobre, H. A. Garverick, and L. L. Anderson. 1997b. Pregnancy rates per 
artificial insemination for cows and heifers inseminated at a synchronized ovulation or synchronized estrus. J. Dairy Sci. 80:295-300.

Rasmussen, F. E., M. C. Wiltbank, J. O. Christensen, and R .R. Grummer. 1996. Effects of fenprostalene and estradiol-17 $\beta$ benzoate on parturition and retained placenta in dairy cows and heifers. J. Dairy Sci. 79:227-234.

Refsal, K. R., J. H. Jarrin-Maldonado, and R. F. Nachreiner. 1987. Endocrine profiles in cows with ovarian cysts experimentally induced by treatment with exogenous estradiol or adenocorticotropic hormone. Theriogenology 28:871-889.

Santos, J. E. P., W. W. Thatcher, L. Pool, and M. W. Overton. 2001. Effect of human chorionic gonadotropin on luteal function and reproductive performance of high-producing lactating Holstein dairy cows. J. Anim. Sci. 79:2881-2894.

SAS User's Guide: Statistics, Version 7th. 1998. SAS Inst., Inc., Cary, NC.

Schillo, K. K. 1992. Effect of dietary energy on control of luteinizing hormone secretion in cattle and sheep. J. Anim. Sci. 70:12711282.

Shelton, K., M. F. GayerieDe Abreu, M. G. Hunter, T. J. Parkinson, and G. E. Lamming. 1990. Luteal inadequacy during the early luteal phase of subfertile cows. J. Reprod. Fertil. 90:1-10.

Sprecher, D. J., R. L. Nebel, and W. D. Whittier. 1988. Predictive value of palpation per rectum vs milk and serum progesterone levels for the diagnosis of bovine follicular and luteal cysts. Theriogenology 30:701-710.

Staples, C. R., W. W. Thatcher, and J. H. Clark. 1990. Relationship between ovarian activity and energy status during the early postpartum period of high producing dairy cows. J. Dairy Sci. 73:938-947.

Stevenson, J. S., Y. Kobayashi, and K. E. Thompson. 1999. Reproductive performance of dairy cows in various programmed breeding systems including OvSynch and combinations of gonadotropin- releasing hormone and prostaglandin F2a. J. Dairy Sci. 82:506-515.

Taylor, C., and R. Rajamahendran. 1991. Follicular dynamics and corpus luteum growth and function in pregnant versus nonpregnant dairy cows. J. Dairy Sci. 74:115-123.

Tenhagen, B. A., M. Drillich, and W. Heuwieser. 2001. Analysis of cow factors influencing conception rates after two timed breeding protocols. Theriogenology 56:831-838.

Thibodeaux, J. K., J. R. Broussard, R. A. Godke, and W. Hansel. 1994. Stimulation of progesterone production in bovine luteal cells by co-incubation with bovine blastocyst-stage embryos or trophoblastic vesicles. J. Reprod. Fertil. 101:657-662.

Vasconcelos, J. L. M., R. W. Silcox, J. A. Lacerda, J. R. Pursley, and M. C. Wiltbank. 1997. Pregnancy rate, pregnancy loss, and response to heat stress after $\mathrm{AI}$ at 2 different times from ovulation in dairy cows. Biol. Reprod. 56(Suppl 1):230.

Vasconcelos, J. L. M., R. W. Silcox, G. L. M. Rosa, J. R. Pursley, and M. C. Wiltbank. 1999. Synchronization rate, size of the ovulatory follicle, and pregnancy rate after synchronization of ovulation beginning on different days of the estrous cycle in lactating dairy cows. Theriogenology 52:1067-1078.

Washburn, S. P., W. J. Silvia, C. H. Brown, B. T. McDaniel, and A. J. McAllister. 2002. Trends in reproductive performance in southeastern Holstein and Jersey DHI herds. J. Dairy Sci. 85:244-251.

Whitmore, H. L., W. J. Tyler, and L. E. Casida. 1974. Incidence of cystic ovaries in Holstein-Friesian cows. JAVMA 165:693-694.

Williams, G. L. 1990. Suckling as a regulator of postpartum rebreeding in cattle: A review. J. Anim. Sci. 68:831-852.

Wiltbank, J. N., W. J. Tyler, and L. E. Casida. 1953. A study of atretic large follicles in six sire-groups of Holstein-Friesian cows. J. Dairy Sci. 36:1077-1082.

Wiltbank, M. C., A. Gümen, and R. Sartori. 2002. Physiological classification of anovulatory conditions in cattle. Theriogenology $57: 21-52$. 